原 著

\title{
鼻内内視鏡手術を行った先天性鼻涙管霊胞例
}

\author{
渡邊 浩基 ${ }^{1)}$, 伊藤 卓 ${ }^{1}$, 山田 雅人 ${ }^{1)}$, \\ 小出 暢章 ${ }^{1)}$, 渡部 大樹 $^{2}$, 今村 公俊 ${ }^{3)}$, \\ ${ }^{4}$ 東京医科歯科大学医学部耳鼻咽喉科
}

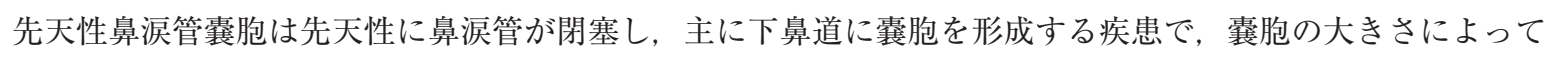
は呼吸障害をきたしうる。今回我々は内視鏡下に造袋術を行った先天性鼻涙管囊胞例を経験したので報告する。 症例は男児で, 出生後からの呼吸障害にて日齢 2 より経鼻持続陽圧送気を行った。鼻内所見では左下鼻道を 占拠し内側に下鼻甲介を圧排する腫瘤性病変を認めた。CT, MRIでは左涙霊, 鼻涙管から下鼻道にかけて連続 する軟部影が見られ, 特徵的な形態から先天性鼻涙管霬胞と診断した。その後, 経過観察中に酸素飽和度の急 激な低下を繰り返し, 人工呼吸器管理となった。呼吸障害の原因として, 喉頭軟化症や喉頭麻痺がないことか

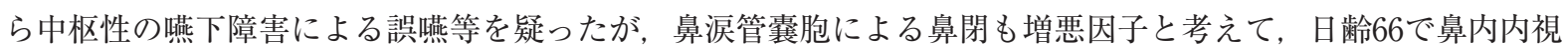
鏡下にマイクロデブリッダーを用いた造袋術を行った。全身麻酔下に細径内視鏡にて左鼻腔内を観察し, 涙点 から中村式涙管洗浄用二段針で希釈ヨード液を注入して涙囊と襄胞の交通を確認した。霊胞はマイクロデブ リッダーを用いて十分に切除した。次に右鼻胿内も観察し, 右下鼻道には病変を認めないことを確認して, 手術を終了した。止血用のパッキングは必要なかった。特に術後合併症は認められず囊胞は完全に開放された が, 呼吸障害は十分に改善されなかった。本症例では呼吸障害の主因は核上性麻痺による嚥下障害と思われた が, 鼻涙管囊胞に対する内視鏡とマイクロデブリッダーを使用した造袋術は安全で効果的な治療法だと考えら れた。

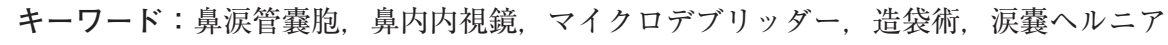

\section{Endoscopic Marsupialization for a Congenital Nasolacrimal Duct Cyst}

\author{
Hiroki Watanabe ${ }^{1)}$, Taku Ito ${ }^{1)}$, Masato Yamada ${ }^{1)}$, Nobuaki Koide ${ }^{1)}$, \\ Hiroki Watanabe $^{2)}$, Masatoshi Imamura ${ }^{3)}$, Yuya Higashi' ${ }^{3)}$, Takeshi Tsutsumi ${ }^{4)}$ \\ ${ }^{1)}$ Department of Otolaryngology, Tsuchiura Kyodo General Hospital \\ ${ }^{21}$ Department of Ophthalmology, Tsuchiura Kyodo General Hospital \\ ${ }^{3}$ Department of Neonatology, Tsuchiura Kyodo General Hospital \\ ${ }^{4}$ Department of Otolaryngology, Graduate School, Tokyo Medical and Dental University
}


A congenital nasolacrimal duct cyst (CNDC) is generally formed due to nasolacrimal duct obstruction during fetal development. Nasolacrimal duct obstruction leads to cystic enlargement of the duct resulting in the formation of an intranasal mass on the inferior meatus. Depending on the site and size, CNDC causes varying degrees of respiratory impairment. We report a male neonate with CNDC. The CNDC was surgically resected using an intranasal endoscopic approach. He presented with respiratory impairment just after birth and was treated with continuous positive airway pressure. An intranasal mass was located on the left inferior meatus. Computed tomography and magnetic resonance imaging showed an enlarged lacrimal sac and a nasolacrimal duct with the mass on the inferior meatus. Because his respiratory impairment became progressively more severe, an intranasal endoscopic marsupialization was performed with a microdebrider to improve his obstructed nasal respiration. Under general anesthesia, direct visualization of the left nasal cavity was performed using a straight telescope with an outside diameter of $2.7 \mathrm{~mm}$.

Endoscopic observation and iodine injection excluded the presence of right nasolacrimal duct cysts. Before marsupialization, the patency of the nasolacrimal duct was confirmed by iodine injection into the lacrimal punctum. The procedure with the microdebrider was carefully performed to prevent injury to the surrounding tissue. Nasal packing to prevent bleeding was not necessary. Although his respiratory state was not fully restored postoperatively, his obstructed nasal respiration was relieved, and no instances of recurrence or complications were noted. Nasal endoscopic marsupialization with a microdebrider represents a safe and effective method for the treatment of CNDC.

Key words : nasolacrimal duct cyst, nasal endoscopy, microdebrider, marsupialization, dacryocystocele

（2016年 5 月 5 日受稿, 2016年 7 月19日受理)

\section{はじめに}

先天性鼻涙管囊胞は先天性に鼻涙管が閉塞することに より, 主に下鼻道に囊胞を形成する疾患である ${ }^{1 \sim 4}$ 。囊胞 の大きさによっては鼻閉を引き起こし, 特に新生児期で

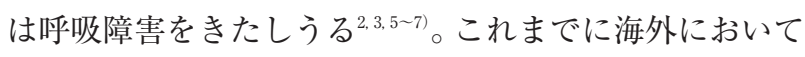
は内視鏡を用いた造袋術の報告があり効果的とされてい $3^{1 \sim 4,7)}$ 。今回我々は, 鼻内内視鏡下にマイクロデブリッ ダーを用いて造袋術を行い, 合併症なく良好な経過をた どった先天性鼻涙管囊胞例を経験したため, 文献的考察 を含め報告する。

\section{症例}

症例：日齢 8 , 男児（在胎38週 4 日）。

主訴：呼吸障害。

家族歴 : なし。

妊娠分娩歴：母親は34歳で 2 経妊 2 経産で自然妊娠。 在胎26週に羊水過多を認め, 羊水検査では明らかな異常 は認めなかった。在胎38週 4 日に頭位経臸分娩にて出生 となった。出生時体重 $3342 \mathrm{~g}$ 。

現病歴：出生後から啼泣, 自発呼吸に乏しくApgar score 1 分 4 点, 5 分 5 点で軽度仮死の状態であった。蘇
生処置にてApgar score 7分30秒 8 点まで改善したが, 努力性呼吸は残存し呼吸性アシドーシス（静脈血pH7.24, $\mathrm{pCO}_{2} 70$ Torr, $\left.\mathrm{HCO}_{3}^{-} 29 \mathrm{mEq} / 1\right)$ が続いたため, 日龄 1 で挿管し人工呼吸器管理となった。日齢 2 で一度抜管 したが, 多量の分泌物が口腔内に貯留し, 再び静脈血 pH7.24, $\mathrm{pCO}_{2}$ 71Torr, $\mathrm{HCO}_{3}^{-} 30 \mathrm{mEq} / 1$ と呼吸状態が悪 化したため, 日齢 4 で経鼻持続陽圧送気（nCPAP）を開 始した。

鼻咽喉頭所見 : 表面平滑で弾性軟の囊胞性病変が左鼻 内下鼻道を占拠していた（図1A）。腫瘤は下鼻甲介を鼻 中隔側上方に圧排して, 左鼻内は閉塞していた。右鼻内, 咽喉頭にその他の占拠性病変は見られず，喉頭軟化症や 喉頭麻痺は認められなかった。流涙や眼脂, 内眼角腫脹 などの所見は認めなかった。

画像所見：呼吸障害の原因検索目的で行われたCTで は左下鼻道を占拠する軟部組織陰影が描出され, 下鼻甲 介を上内側へ圧排・偏位させていた（図2B，D）。左涙 囊は軽度拡張し，鼻涙管は周囲の骨も含めて拡張してい た（図2C）。MRIではT2強調画像にて涙囊, 鼻涙管から 下鼻道にかけて連続する高信号の病変が確認された (図2E，F)。CT, MRIで脳内に明らかな異常所見を認め なかった。 


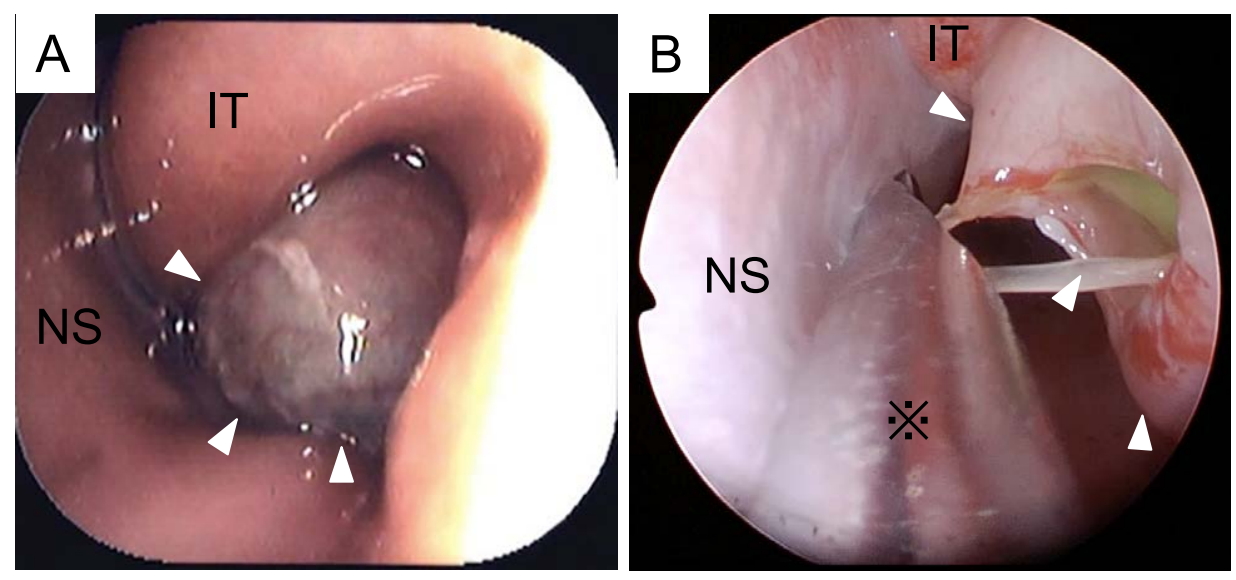

図 1 鼻内内視鏡所見。襄胞は下鼻甲介（IT）を鼻中隔（NS）側に圧排し下鼻道を占拠していた（図A）。マイクロデブリッダー (※) で囊胞壁を切除した（図B）。
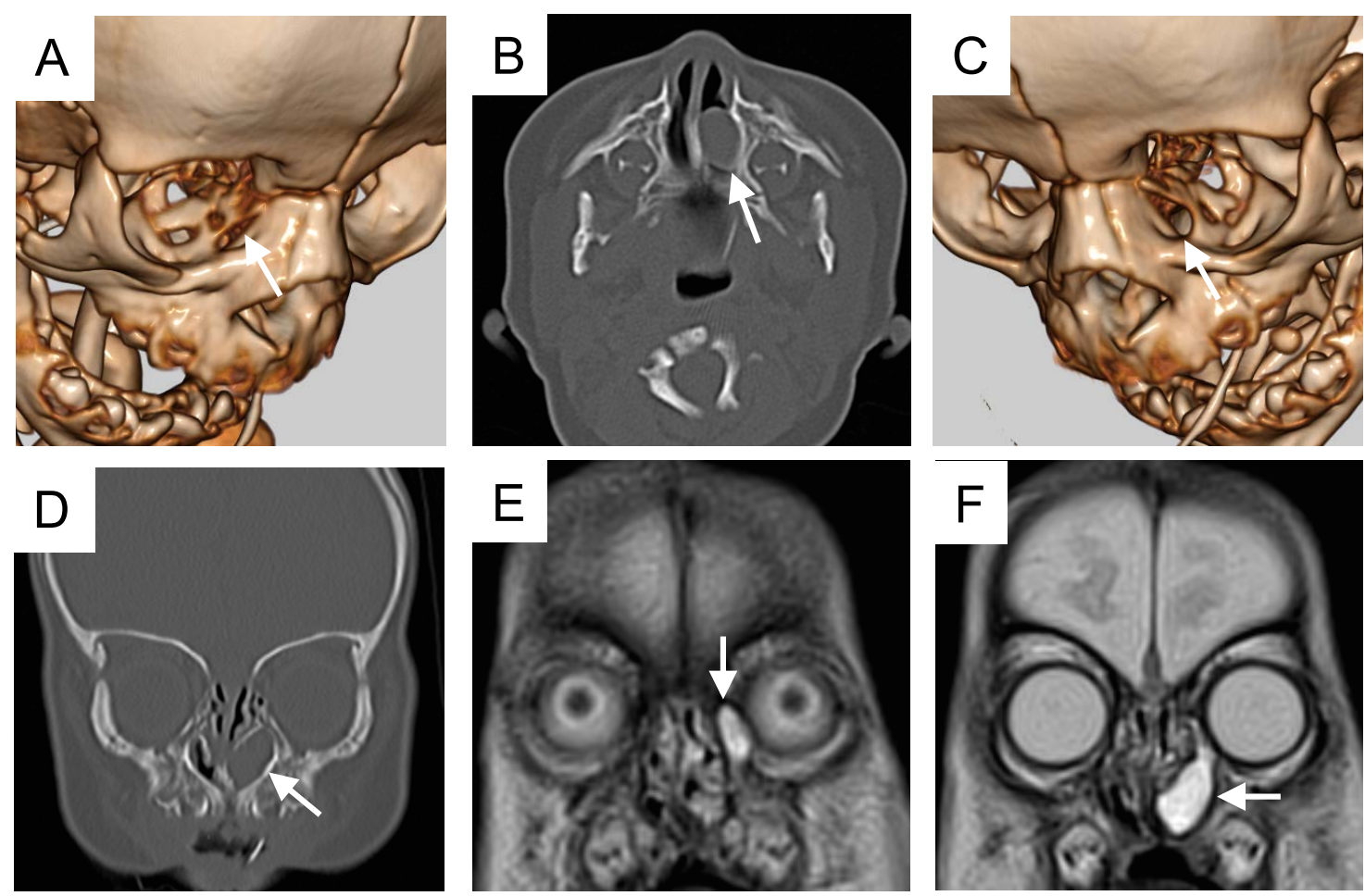

図2 画像所見。単純CTでは均一な腫瘤が鼻涙管開口部付近に存在（B）し，下鼻甲介を内側上方へ圧排している（D）。3DCT にて患側（C）で腫瘤に一致して骨性鼻涙管が健側（A）に比べて拡大している。MRI T2強調画像冠状断で高信号病変が 涙囊から鼻涙管，鼻内へと連続する $(\mathrm{E}, \mathrm{F})$ 。

臨床経過：鼻内所見，および特徵的な画像所見から 左鼻涙管囊胞と診断し, 出生間もないことと片側性であ ること, nCPAPにて酸素飽和度 $90 \%$ 台後半, 静脈血 pH7.36, $\mathrm{pCO}_{2}$ 63Torr, $\mathrm{HCO}_{3}^{-} 35 \mathrm{mEq} / 1$ とある程度落ち 着いていたことから経過観察とした。しかしその後, 日 齢28から29にかけて酸素飽和度の急激な低下 (30-60\%程 度）を繰り返し，用手的な人工換気と酸素投与にて回復
はするものの，頻度が多いため再び挿管し人工呼吸器管 理となった。呼吸障害の原因として, 喉頭軟化症や喉頭 麻痺がないことから中枢性の與率下障害による誤嚥等によ る影響を考えたが，増悪因子として鼻涙管囊胞による鼻 閉が関係している可能性を考慮して日齢66で手術治療を 行った。

手術：全身麻酔をかけた後, 5000倍希釈アドレナリン 
入りガーゼを両鼻内に摴入した。ガーゼを抜去した後, 直径 $2.7 \mathrm{~mm}$ の $0^{\circ}$ 細径内視鏡（カールストルッ・エンドス コピー・ジャパン株式会社）を用いて左鼻内を観察した。 囊胞性病変は左下鼻道を占拠するように位置しており, アドレナリン入りガーゼ挡入時に一部破れた囊胞壁から 膿汁が流出していた。囊胞性病変と涙囊との交通を確認 するため, 涙点から中村式涙管洗浄用二段針を挿入し, 希釈ヨード液を注入した。希釈ヨード夜は抵抗なく破れ た震胞壁から流出し, 鼻涙管囊胞と確定診断した。次に, 囊胞壁の切除を行うため, $2 \mathrm{~mm}$ のローテータブルター ビネートブレード（\#1882040HR， 日本メドトロニック 株式会社）を装着したマイクロデブリッターを鼻内に 扱入した。回転数は3000rpmに設定し, 周囲構造物を損 傷しないよう留意し囊胞壁を十分に切除した（図1B)。 最後に再び涙点から希釈ヨード液を注入して, 襄胞壁の 切除が十分であることを確認した。出血は少量であった ため止血用のパッキングは必要としなかった。最後に, 右鼻内も観察して右下鼻道に襄胞性病変が存在しないこ と, 希釈ヨード液の注入で鼻涙管閉塞がないことを確認 した。

病理所見：囊胞壁は通常の鼻腔粘膜と同様の多列線 毛上皮で覆われていた。間質にはリンパ球浸潤を認めた (図 3 )。

術後経過: 術中の囊胞内容物からの細菌培養では, メチシリン耐性黄色ブドウ球菌（Methicillin-resistant Staphylococcus aureus, MRSA）が検出された。術後, 左鼻 腔の換気は良好となり, 鼻呼吸は可能となった。しかし

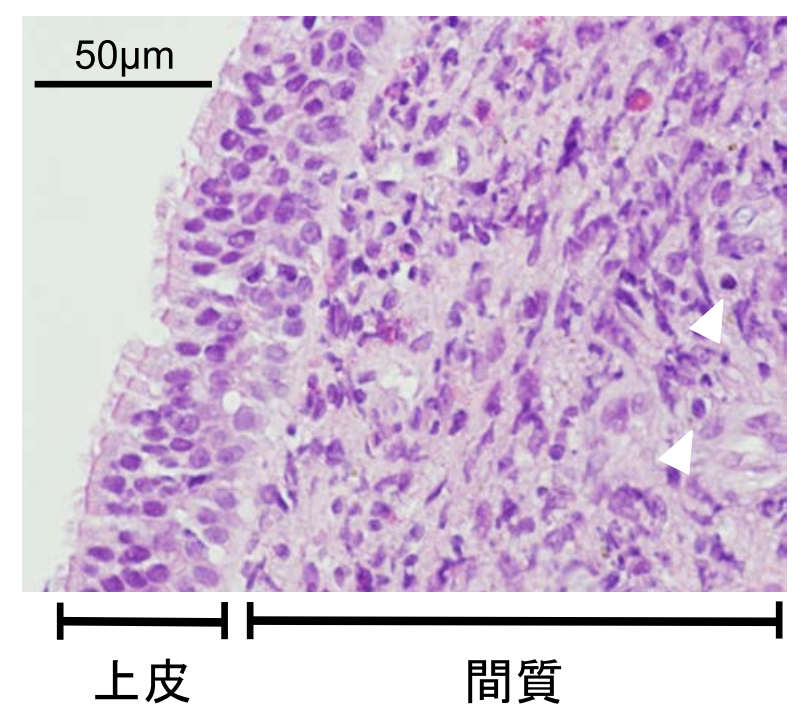

図3 病理学的所見。(HE染色) 異胞壁は鼻腔側で通常の鼻 腔粘膜と同様の多列線毛上皮で覆われており，間質に はリンパ球浸潤（矢頭）を認めた。
その後も呼吸障害は完全には改善せず, 術後 3 週間で再 度挿管管理となった。呼吸障害の原因については核上性 麻痺による嚥下障害, 誤嚥と考えられ, 気管切開が施行 された。な㧍,術後 8 か月で囊胞の再発は認めていない。

\section{考察}

涙腺で分泌された涙液は上下の涙点を通って, 涙小 管, 涙囊, 鼻涙管を経て下鼻道に開口する。この涙道は 胎児期に内側鼻突起と上顎突起の間の外胚葉表面より 発生し, 最終的に鼻涙管遠位端が開通し下鼻道に通ず る ${ }^{7.8)}$ 。先天性鼻沪管囊胞は一般的には涙囊開口部にあ るRosenmüller弁の機能的閉塞と鼻涙管遠位端にある

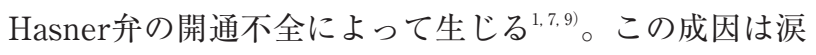
襄ヘルニアと同様である。基本的には鼻淚管が拡張する とその解剖学的特性から, 涙囊も同様に拡張するため, 鼻涙管囊胞と涙囊ヘルニアは同義で呼称される場合が ある。この 2 疾患の定義は文献によって異なり曖昧であ る ${ }^{1133}$ が, 本論文では囊胞が涙囊の前方に突出するものを 涙囊ヘルニア, 襄胞が下鼻道に突出するものを鼻涙管襄 胞として論じる。先天性鼻涙管囊胞は必ずしも涙囊へル ニアを伴うわけではなく, 本症例のように単独で発症し 呼吸障害を引き起したとの報告もある3.77。

海外に打いては先天性涙囊へルニアは約 $0.02 \%$ 新 生児に見られ $れ^{10)}$, 先天性鼻涙管囊胞の発症頻度は約 $0.2 \%$ 程度と報告されている11)。しかし，本疾患が鼻閉による 呼吸障害を引き起こしたとの報告はごくわずかしか見 られないため, 多くのものは無症状で過ごすか, 自然治 癒しているものと思われる。実際, 先天性鼻涙管閉塞は ほとんどの例で生後 1 年以内に自然治癒するとされてい $ろ^{8.11,12)}$ 。

元来, 新生児は鼻呼吸が中心のため, 鼻胿内の閉塞の 程度によっては呼吸障害や哺乳障害をきたすことがあ る。本疾患でも，巨大な囊胞による鼻閉によって生後の 重篤な呼吸障害が発症することがある 源 $^{2,5-7)}$ 。多くは両側 性のものであるが，中には片側性でも呼吸障害を発症す ることが報告されている6 。その他の症状としては涙囊 炎をきたすことが多く, 重症化し蜂窩織炎となることも ある。治療は, プロービング, 涙道ステント, 涙道洗浄, 襄胞穿刺, 内視鏡による襄胞造袋術，あるいはnCPAPな ど様々な方法が報告されている の低い保存的治療を行うことが多いが, 呼吸障害や涙囊 炎などの感染を認める場合には早期の外科的手術, 特に 襄胞造袋術が必要とされる6.99。感染を伴わず呼吸障害の み認める場合にはnCPAPが有効との報告9)あり, 今回 我々はnCPAPにて経過を観察するも, 徐々に呼吸状態が 
悪化していたため, 全身麻酔下にマイクロデブリッダー を用いた鼻内内視鏡下の造袋術を行った。治療法の選択 に際しては，患児が择管管理を必要とする重度の呼吸障 害を呈し改善を認めない点と本疾患が呼吸障害の一因で ある可能性を考虑し，早期の外科的手術の方針とした。 また，過去の文献にて複数例報告されており安全で効果 的と報告されている本手術法を選択した ${ }^{3.4)}$ 。今回の手術 法の利点としては, 全身麻酔下で行うことによって術中 に膿を含む多量の貯留物の誤嚥を避けられることや患児 の体動による鼻内周囲の損傷を防げること, さらにはマ イクロデブリッダーを使用することで周囲をなるべく損 傷することなく䧶胞壁を十分に除去できることがあげら れる ${ }^{3,4,12)}$ 。また, 我々耳鼻咽㑨科医にとって, 鼻内内視 鏡下副鼻腔手術と同様の手技で行うことができ，術者に 特別な手術技術は必要としない。手術は細径の内視鏡を 使うことによって, 新生児の小さな鼻内であったとして も良好な視野を取ることができ，操作もしやすい立。

本疾患は両側性にも発症しうる疾患であるため, 術中 に両側ともに下鼻道をしっかり観察し鼻涙管が閉塞して いないことを確認することが推奨されている, 囊胞壁を十分に切除していれば術後の涙道ステント留置 は行わなくても再発しないとされている3.4)。本症例も片 側性の発症で, 対側の鼻涙管も希釈ヨード液の注水で涙 道の閉塞を認めなかったことを確認した。涙道ステント は留置しなかった。ただし，再閉塞などの術後合併症は 数週以内に起きるとされているが，邆発性に発症した報 告もあるため, 1 年以上の経過観察が推奨されている,7)。 本症例では術後 8 か月において, 再発を認めていないが継 続的な経過観察を行っていく必要があると考えている。

\section{結 語}

1. 新生児に認められた先天性鼻涙管囊胞例を経験した。

2.内視鏡とマイクロデブリッダーを使用した造袋術は 安全で効果的な治療法であった。

\section{参考文献}

1) Wang JC, Cunningham MJ : Congenital dacryocystocele: Is there a familial predisposition? Int J
Pediatr Otorhinolaryngol $2011 ; 75$ : 430-432.

2) Jin HR, Shin SO : Endoscopic marsupialization of bilateral lacrimal sac mucoceles with nasolacrimal duct cysts. Auris Nasus Larynx 1999 ; 26 : 441-445.

3) Dogan E, Yuksel NG, Ecevit MC, et al : Microdebrider assisted endoscopic marsupialization of congenital intranasal nasolacrimal duct cysts. Int J Pediatr Otorhinolaryngol $2012 ; 76$ : 488-491.

4) Friedman NR, Luck M, Scapa VI : Excision of congenital nasolacrimal duct cyst with powered instrumentation. Laryngoscope $2011 ; 121: 135-136$.

5 ) Mansour AM, Cheng KP, Mumma JV, et al : Congenital dacryocele. A collaborative review. Ophthalmology 1991 ; 98 : 1744-1751.

6 ) Paysse EA, Coats DK, Bernstein JM, et al : Management and complications of congenital dacryocele with concurrent intranasal mucocele. J AAPOS $2000 ; 4: 46-53$.

7 ) Shashy RG, Durairaj VD, Holmes JM, et al : Congenital dacryocystocele associated with intranasal cysts: Diagnosis and management. Laryngoscope $2003 ; 113: 37-40$.

8 ) Cassady JV : Developmental anatomy of nasolacrimal duct. AMA Arch Ophthalmol $1952 ; 47: 141-158$.

9) Kuboi T, Okazaki K, Kusaka T, et al : Congenital dacryocystoceles controlled by nCPAP via nasal mask in a neonate. Pediatr Int $2015 ; 57$ : 475-477.

10) Li SL, Luo GY, Tian XX, et al : Prenatal diagnosis and perinatal outcome of congenital dacryocystocele: A large case series. Prenat Diagn 2015 ; 35 : 103-107.

11) MacEwen CJ, Young JD : Epiphora during the first year of life. Eye $1991 ; 5: 596-600$.

12）廣瀬美央：【涙道領域一最近の話題】先天鼻涙管閉 塞.あたらしい眼科 $2013 ； 30 ： 903-907$.

13）鈴木佑佳, 松本 直, 和田弘太, 他: 先天性涙襄へ ルニアに対して18ゲージ針を用いた造袋術を行い治 癒した 1 例。臨眼 $2014 ； 68 ： 1483-1486$. 